\title{
UCRL-TR-215380
}

LAWRENCE LIVERMORE N A T IO N A L LABORATORY

\section{Advanced Fuel Cycle Initiative (AFCl) Repository Impact Evaluation FY-05 Progress Report}

W. G. Halsey

September 15, 2005 
This document was prepared as an account of work sponsored by an agency of the United States Government. Neither the United States Government nor the University of California nor any of their employees, makes any warranty, express or implied, or assumes any legal liability or responsibility for the accuracy, completeness, or usefulness of any information, apparatus, product, or process disclosed, or represents that its use would not infringe privately owned rights. Reference herein to any specific commercial product, process, or service by trade name, trademark, manufacturer, or otherwise, does not necessarily constitute or imply its endorsement, recommendation, or favoring by the United States Government or the University of California. The views and opinions of authors expressed herein do not necessarily state or reflect those of the United States Government or the University of California, and shall not be used for advertising or product endorsement purposes.

This work was performed under the auspices of the U.S. Department of Energy by University of California, Lawrence Livermore National Laboratory under Contract W-7405-Eng-48. 


\section{Advanced Fuel Cycle Initiative}

\section{$\underline{\text { AFCI Repository Impact Evaluation }}$ \\ FY-05 Progress Report}

September 15, 2005

W. G. Halsey

Lawrence Livermore National Laboratory California, Lawrence Livermore National Laboratory under Contract No. W-7405-Eng-48. 


\title{
AFCI Repository Impact Evaluation FY-05 Progress Report
}

\begin{abstract}
Workscope: As part of the continuing interface for mutual benefit between AFCI and the OCRWM repository program, Repository Benefit participants at LLNL, ANL and INEEL provide assessment of how AFCI technology and repository technology can optimize the future evolution of the fuel cycle. Evaluation of repository technical issues provides feedback on critieria and metrics for AFCI, and evaluation of AFCI waste streams provides technical alternatives for future repository optimization. LLNL coordinates this effort which includes repository analysis at ANL and incorporation of repository impacts into AFCI criteria at INEEL. Cooperative evaluation with YMP staff will be pursued to provide a mutually agreed technical base. Cooperation with select international programs is supported.
\end{abstract}

\section{Introduction}

An important long-term objective of advanced nuclear fuel cycle (AFC) technologies is to provide improvement in the long-term management of radioactive waste. Compared to a oncethru fuel cycle, it is possible to generate far less waste, and potentially easier waste to manage, with advanced fuel cycles. However, the precise extent and value of these benefits are complex and difficult to quantify ${ }^{1}$. This document presents a status report of efforts within AFCI Systems Analysis to define and quantify the AFC benefits to geologic disposal, development of cooperative efforts with the US repository program, and participation with international evaluations of AFC impacts on waste management. The primary analysis of repository benefits is conducted by ANL. This year repository impact evaluations have included:

- Continued evaluation of LWR recycle benefits in support of scenario analysis.

- Extension of repository analyses to consider long-term dose reductions.

- Developing the opportunity for cooperation with the U.S. repository program.

- International cooperation with OECD-NEA.

\section{Summary of FY-05 AFCI Repository Impact Developments}

Interest in the use of recycle in current and Gen-III light water reactors continued in FY-05, and drove repository analysis to new levels of detail. Such thermal recycle could permit earlier introduction of AFC benefits for waste management. Results have been reported separately by ANL and other systems analysis reports. 
Developments in the Yucca Mountain Project also impact the focus of AFCI Repository Impact evaluations. Completion of the license application early in the fiscal year provided an opportunity for joint $\mathrm{AFCI} / \mathrm{RW}$ consideration of the longer-term future of waste management, until delay of the application and the subsequent focusing of repository technical staff on completion of the license support system data base deferred further cooperative work. Progress on revision of the EPA regulation ${ }^{2}$ (40 CFR 197 proposed revision, August 2005) has brought further focus to evaluation of long-term dose from AFCI scenarios.

\section{FY-05 AFCI Repository Impact Analyses \& Support to Other Systems Studies}

AFCI analyses for repository benefit in FY-05, primarily conducted at ANL, included repository thermal/capacity evaluations in support of other systems studies (and reported elsewhere by those activities). This year includes development of the capability at ANL for simplified repository performance analysis to examine long-term dose benefits from AFCI scenarios. A report "Repository Benefits of AFCI Options - Radiotoxicity and Dose Rate", R.A. Wigeland, E.E. Morris, and J.A. Stillman, Argonne National Laboratory, December 23, 2004 documents this new analysis capability.

\section{Support to AFCI 2005 Report to Congress:}

The Repository Impacts staff contributed to development of the AFCI March 2005 Report to Congress through development of quantitative objectives and metrics for waste management optimization, as well as supporting repository capacity evaluations.

Support to Transmutation Analysis:

ANL Repository Impacts staff supported transmutation studies with applications of relative repository capacity based on thermal decay heat calculations. The potential capacity increase for different separation efficiencies and with various approaches to short half-life radionuclides has been calculated. With very high separation factors (99.9\%) and separate management of shortlife fission products, thermal capacity improvements of more than $100 \mathrm{X}$ are possible.

Support to Thermal Recycle Evaluation:

Repository Impacts staff supported development of the Systems Analysis Thermal Recycle Recommendation Report. This work also responded to NERAC-ANTT questions regarding repository thermal capacity and dose rate impacts of various thermal reactor recycle strategies, specifically including inert matrix $\mathrm{Pu}$ and $\mathrm{Pu}+\mathrm{MA}$ fuels. Results indicate that thermal recycle can provide substantial repository benefits providing recycle continues or another disposition path is developed for eventual management of spent recycle fuel (ie. fast reactors, transmutation, etc.). Single LWR recycle only provides marginal benefit. Multiple thermal recycle in current technology reactors can defer the need for other waste management improvements for many decades. For single cycle IMF fuels, use of $\mathrm{Pu}-\mathrm{IMF}$ can provide significant benefit, but incorporation of other actinides $(\mathrm{Np}, \mathrm{Am})$ can provide limited benefit thermally but may be worse from a dose perspective.

$\underline{\text { EBR-II Blanket Disposal }}$ 
Further evaluation of geologic repository implications of EBR-II blanket disposal following sodium distillation were deferred to permit focus on other priorities. Renewed interest in faster/cheaper disposition pathways may renew this effort.

\section{Cooperative Work with DOE-RW/YMP}

There has been significant progress in the cooperation between the DOE-NE AFCI program and the DOE-RW Yucca Mountain Project. As the YMP baseline for the license application has become finalized, the ability to define the impacts of "beyond the YM baseline" changes to the future of radioactive waste management has improved. AFCI technology is one major potential change to the future of waste management. The interface between the two programs can be divided into two parts; A) a 'top-down' effort to develop a formal joint working group chartered by both DOE offices to serve in an ongoing coordination and joint analysis role, and B) a 'bottom-up' effort to engage YM technical staff in specific technical analysis of mutual interest.

\section{Spent Fuel Management Steering Committee:}

With support from senior DOE staff from both DOE-NE and DOE-RW, AFCI Systems Analysis staff from INEEL arranged the formation of a joint working group including DOE, laboratory and consultant staff from AFCI and YMP. One primary effort for this group is to plan the cooperative input to a Secretarial Report on the Need for a Second Repository as mandated in the Nuclear Waste Policy Act (as amended) for delivery to the President and the Congress in the 2007-2010 timeframe. While it is expected that DOE-RW will lead the report preparation, the AFCI appropriation language directs DOE-NE to contribute potential impacts of advanced fuel cycle technologies.

An initial meeting of the steering committee was held in Washington DC on October 13, 14, 2004. This meeting expanded the dialog between the AFCI program and the Office of Civilian Radioactive Waste Management in areas of mutual interest. A path forward for cooperation was developed including near-term development of mutually agreed terminology and statements, mid-term development of coordinated schedules and joint analysis, and long-term cooperation on the future of fuel cycle and waste management beyond the YMP baseline.

A second meeting of the committee was held in Washington DC on December 7-8, 2004. It was agreed by DOE staff that the committee would take on a number of challenges including a review of waste management options for the future and evaluation of geologic disposal beyond the Yucca Mountain baseline. A first draft of a combined high-level schedule showing critical milestones and decision points for the two programs was produced by SNL staff. To organize planned future analyses, three working groups were created, each with initial charter, membership and working assumptions. The titles and summary assignment for these working groups are:

- Integrated Systems Model: Develop a joint systems model including quantities and timing of wastes, nuclear demand options, disposal options, and eventual cost basis.

- Waste Streams: Develop waste characteristics for AFCI options including isotopic loads, waste forms, range of fuels, and share waste form performance data with Repository Performance WG 
- Repository Performance: Assess repository impacts of AFCI waste forms, pre-closure operations, post-closure performance, preliminary look at alternate design strategies and disposal options, and evaluate the potential 'technical' capacity assessment of Yucca Mountain.

In addition, DOE has begun to revise a prior draft of a MOU between the two offices to serve as a working charter for the committee.

DOE-NE (AFCI) and DOE-RW (OCRWM) continue to plan for cooperative input to the President and the Congress in the 2007 - 2010 timeframe on the need for a second geologic repository, as mandated by The Nuclear Waste Policy Act.

\section{Yucca Mountain Technical Analysis}

A process for interaction with Yucca Mountain project staff at the technical working level has been developed. Through discussions with YMP M\&O contractor (Bechtel-SAIC Corp.) management in Las Vegas, we obtained approval for YMP technical staff to respond to requests for information and analysis from AFCI - Systems Analysis regarding repository impacts. This is initially done through LLNL YMP staff in Las Vegas co-funded by AFCI. The initial test request addressed questions regarding thermal management, waste form, waste package and repository design. Responses were received from $\mathrm{YMP}^{3}$. This establishes a pathway for technical information exchange at the working level. It is desired to develop this activity into an ongoing venue for 'beyond the YMP baseline' technical cooperation between AFCI and YMP. The technical content of the Letter Report received from YMP is included as Appendix A of this report.

\section{International Cooperation}

OECD-NEA has an international experts group conducting a study study "Impacts of Advanced Fuel Cycles on Waste Management Policy". DOE-NE (AFCI) and DOE-RW (OCRWM) are supporting U.S. participation in this study, primarily by AFCI Repository Benefits staff. This study has selected fuel cycle scenarios for analysis, developed flowsheets and defined waste streams from these flowsheets. The group determined to use fuel cycle cost as a common metric to evaluate the variety of waste management impacts. For this analysis, the group has developed unit costs for each process and mass flow in the scenarios. Other metrics will include repository design issues such as capacity, and repository performance represented by long-term dose calculations.

A dozen scenarios are under evaluation including open cycle, single cycle MOX, multi-cycle $\mathrm{MOX}, \mathrm{Pu}+\mathrm{Am} \mathrm{LWR}$ recycle, $\mathrm{Pu}+\mathrm{Am}+\mathrm{Cm}$ recycle in fast spectrum metal cooled and gas cooled reactors and recycle with ADS options. Processes include UREX, PUREX and Pyro, and metal, oxide and nitride fuels. Several scenarios include processes directly related to AFCI R\&D including UREX+ and Pyro processing, and metal, oxide and nitride fuels containing minor actinides. U.S. participation is continuing to assure that the results of the evaluation are consistent with AFCI and DOE-RW perspectives. With joint support from AFCI and DOE-RW, LLNL AFCI staff serves as Chair of Working Group \#3, which is responsible for evaluating the impact of the AFC waste streams on geologic disposal. 
The NEA study selected four representative fuel cycle scenarios for most detailed evaluation including repository impacts. These scenarios are:

- Scenario 1a - PWR, open cycle, $\mathrm{UO}_{2}$ fuel (this is the reference scenario)

- Scenario $1 \mathrm{~b}$ - PWR, PUREX reprocessing, single recycling of $\mathrm{Pu}$ as MOX

- Scenario 2a - PWR, PUREX reprocessing, multi-recycling of Pu as MOX

- Scenario 3c variant 1 - GCFR, pyro-reprocessing, carbide fuel.

Because repository impacts vary for different repository types, it was desired to include evaluation of the selected scenarios for four different repository types: bedded salt, saturated granite, saturated clay and unsaturated volcanic rock. During FY-05 this work was supported by analysis at ANL that extended existing AFCI repository thermal capacity calculations and repository performance calculations for the NEA scenarios and an unsaturated tuff rock repository like that proposed for Yucca Mountain ${ }^{4}$. This analysis was summarized as input to NEA, which is shown in Appendix B of this report.

\section{Summary and Path Forward}

Systems analyses of potential repository benefits from AFC scenarios have been conducted and coordinated with other systems studies and transmutation studies. As each type of analysis matures, it becomes a base of support for other parts of AFCI. The repository thermal capacity analysis has become such a base, and repository dose calculations are in the process of maturing to this level. Opportunities for expanded cooperation with DOE-RW were developed during the past year with remarkable progress. Future effort to build on this cooperation are important to developing a mutually agreed basis for long-term waste management possibilities.

In FY-06 the repository benefit activities will be combined with consideration of the disposition of all output streams from advanced fuel cycles in a broader "Storage and Disposal" activity.

\section{References}

1) "AFCI Repository Impact Evaluation Report: Systems Analysis Progress Report - FY03", W. Halsey, UCRL-ID-155287, Lawrence Livermore National Laboratory, Livermore, CA,

2) "40 CFR 197 Public Health and Environmental Radiation Protection Standards for Yucca Mountain, Nevada,; Proposed Rule", US Environmental Protection Agency, August 2005.

3) "Transmittal of DOE-RW information to the DOE-NE AFCI Program regarding the proposed Yucca Mountain repository", J. A. Blink, ETD 05-12-19, Internal communication, Lawrence Livermore National Laboratory, Livermore, CA., December 2004.

4) "Partitioning and Transmutation "Expert Group" Performance Assessment of Recycle Waste Streams sent to a Geologic Repository Located in Tuff', R. A. Wigeland, E. E. Morris, T. H. Bauer, Argonne National Laboratory, Letter Report to W. G. Halsey - LLNL, June 2005. 


\section{APPENDIX A \\ Letter Report: \\ Technical Input Received from YMP M\&O in Response to AFCI Questions ${ }^{3}$}

As the DOE-RW program evolves past License Application (LA), results from the extensive preLA analyses will become available for use by the AFCI program in comparative analyses. Until then, information from existing DOE-RW documents can be used by the AFCI program. However, it should be noted that the models have evolved since those existing documents were published and will likely evolve further during the first half of CY2005.

The AFCI Program requested the following five items of information:

1) Dose by Radionuclide, Time, and Scenario Class

Request: "Isotope by isotope breakdown of the "toxicity" and various dose calculations for YMP. The EIS and S+E reports only have the total over all isotopes. I'd like to look at the isotope-by-isotope numbers (preferably in tabular form) for SNF for the various dose scenarios. Many of the underlying documents are no longer readily available. Ideally, I'd love to get $\mathrm{Sv} / \mathrm{year}$ for each isotope for each pathway for different time periods after emplacement. Dose by Radionuclide, Time, and Scenario Class."

Information Provided: The differences between repository performance for the once through waste stream and the AFCI waste stream are obscured by engineered barrier performance for 10,000-year calculations. Therefore, this letter transmits calculations for 1,000,000 years for the nominal scenario class and for 100,000 years for the igneous scenario class. These calculations were performed in support of the Final Environmental Impact Statement (FEIS).

The calculations are documented in

YMP Accession Number MOL.20011213.0056, Letter from N. Williams (BSC) to J. Summerson (DOE-RW), December 11, 2001, "Contract No. DE-AC08-01RW12101 Total System Performance Assessment - Analyses for Disposal of Commercial and DOE Waste Inventories at Yucca Mountain - Input to Final Environmental Impact Statement and Site Suitability Evaluation Rev 00 ICN 02".

That letter cited a Bechtel SAIC Company, LLC, internal memorandum with YMP Accession Number MOL.20010926.0009, from G. Saulnier to J. McNeish (BSC), September 26, 2001, "Delivery of Input and Output Files Used in the Analyses for Disposal of Commercial and DOE Waste Inventories at Yucca Mountain - Input to Final Environmental Impact Statement and Site Suitability Evaluation".

The memorandum includes seven CDs with GoldSim results.

This letter to the AFCI program includes extracted results from the CDs. The results are summarized in Figure 1, which shows the mean annual dose for the nominal and igneous 
scenario classes, and from stylized human intrusions at 100 and 30,000 years. Tables 1 and 2 show results for the nominal and igneous scenario classes, by radionuclide, for selected times. The CDs include larger tables that were used to plot Figure 1; these tables are summarized on an Excel spreadsheet that Dr. Blink can e-mail to Dr. Halsey on request.

Several radionuclides included on the CDs, which have a standard format, are not shown in Tables 1 and 2, for the following reasons:

- "Radionuclides" Ic237 through Ic243 represent doses attributable to radionuclides transported on colloids. The Performance Assessment has the capability to separate these doses from those of the same radionuclides transported in solution. The larger tables include the totals (colloidal and dissolved transport) for each radionuclide, and the Ic237 through Ic243 columns simply contain zeros.

- Radionuclide U235 is calculated in the Performance Assessment, as a precursor to Ac227. However, the U235 direct contribution to dose is not calculated (the Biological Dose Conversion Factor, BDCF, is set to zero). The column for U235 therefore has all zeros.

- Radionuclides Th232 and Ra228 are calculated in the Performance Assessment, to evaluate compliance with the groundwater protection standard. However, their direct contributions to dose are not calculated (their BDCFs are set to zero). The columns for Th232 and Ra228 therefore have all zeros.

- The column "col" is a totals column for doses from radionuclides transported by colloids. Because the colloid contributions are included in the radionuclide columns, rather than separated into the Ic237 through Ic243 columns, the "col" column has all zeros. 
Figure 1: Mean annual dose for the Nominal and Igneous Scenario Classes and for human intrusion, as calculated for the FEIS.

\section{Results from the Final EIS for Yucca Mountain}

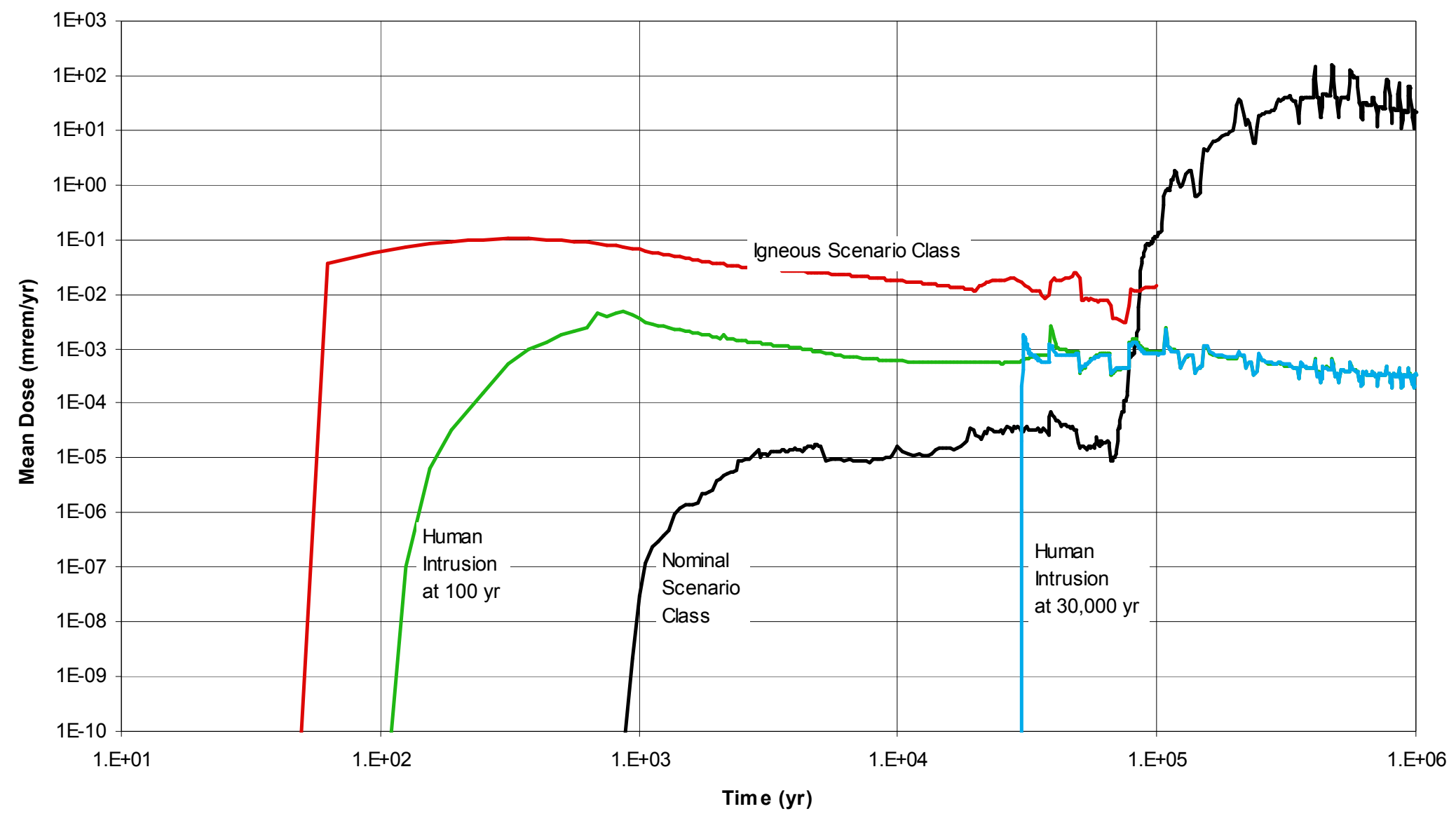


Table 1: Mean annual Dose, by radionuclide, for the Nominal Scenario Class, from the FEIS calculation.

\section{Model Case: SE01_006nm6 Nominal Scenario Class \\ Description: $\quad$ EIS 70,000 MTHM-Scenario for HTOM (300 realizations, 1e6 years)}

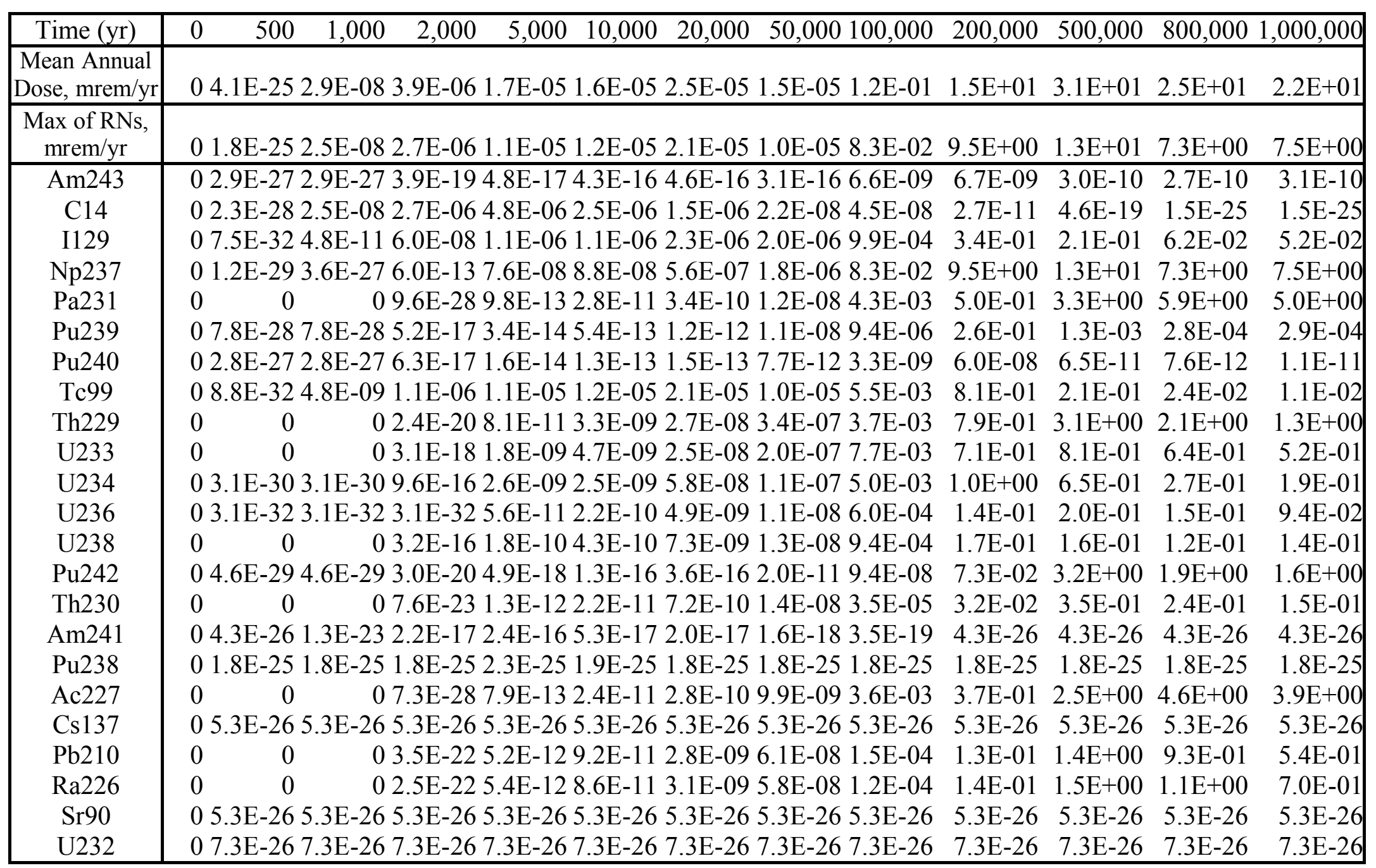


Table 2: Mean annual Dose, by radionuclide, for the Igneous Scenario Class, from the FEIS calculation.

\begin{tabular}{|c|c|}
\hline | Case: & SE01_001im5 \\
\hline
\end{tabular}

\begin{tabular}{|c|c|c|c|c|c|c|c|c|c|}
\hline Time (yr) & 0 & 500 & 1,000 & 2,000 & 5,000 & 10,000 & 20,000 & 50,000 & 100,000 \\
\hline $\begin{array}{c}\text { Mean Annual Dose, } \\
\text { mrem/yr }\end{array}$ & 0 & $9.7 \mathrm{E}-02$ & $6.4 \mathrm{E}-02$ & $3.6 \mathrm{E}-02$ & $2.4 \mathrm{E}-02$ & $1.8 \mathrm{E}-02$ & $1.2 \mathrm{E}-02$ & $1.9 \mathrm{E}-02$ & $1.4 \mathrm{E}-02$ \\
\hline $\begin{array}{c}\text { Max of RNs, } \\
\mathrm{mrem} / \mathrm{yr}\end{array}$ & 0 & $6.5 \mathrm{E}-02$ & $3.3 \mathrm{E}-02$ & $1.7 \mathrm{E}-02$ & $1.2 \mathrm{E}-02$ & $9.7 \mathrm{E}-03$ & $7.8 \mathrm{E}-03$ & $1.5 \mathrm{E}-02$ & $8.8 \mathrm{E}-03$ \\
\hline Am243 & 0 & $9.5 \mathrm{E}-04$ & $1.0 \mathrm{E}-03$ & $9.3 \mathrm{E}-04$ & $7.0 \mathrm{E}-04$ & $4.4 \mathrm{E}-04$ & $1.8 \mathrm{E}-04$ & $1.6 \mathrm{E}-04$ & $1.2 \mathrm{E}-05$ \\
\hline $\mathrm{C} 14$ & 0 & $8.5 \mathrm{E}-13$ & $4.5 \mathrm{E}-07$ & $2.4 \mathrm{E}-05$ & $3.7 \mathrm{E}-05$ & $5.5 \mathrm{E}-05$ & $3.7 \mathrm{E}-05$ & $1.3 \mathrm{E}-06$ & $5.5 \mathrm{E}-09$ \\
\hline I129 & 0 & $2.6 \mathrm{E}-12$ & 7.3E-08 & $1.1 \mathrm{E}-06$ & $1.7 \mathrm{E}-05$ & $3.1 \mathrm{E}-05$ & $8.0 \mathrm{E}-05$ & $1.7 \mathrm{E}-04$ & $3.2 \mathrm{E}-04$ \\
\hline Np237 & 0 & $4.3 \mathrm{E}-05$ & $6.0 \mathrm{E}-05$ & $6.8 \mathrm{E}-05$ & $8.1 \mathrm{E}-05$ & $8.8 \mathrm{E}-05$ & $1.7 \mathrm{E}-04$ & $1.1 \mathrm{E}-03$ & $2.8 \mathrm{E}-03$ \\
\hline $\mathrm{Pa} 231$ & 0 & $3.2 \mathrm{E}-07$ & $3.7 \mathrm{E}-07$ & 4.1E-07 & $1.4 \mathrm{E}-06$ & $2.7 \mathrm{E}-06$ & $1.9 \mathrm{E}-05$ & $3.9 \mathrm{E}-04$ & $3.8 \mathrm{E}-04$ \\
\hline $\mathrm{Pu} 239$ & 0 & $1.1 \mathrm{E}-02$ & $1.2 \mathrm{E}-02$ & $1.2 \mathrm{E}-02$ & $1.1 \mathrm{E}-02$ & 9.7E-03 & $7.8 \mathrm{E}-03$ & $1.5 \mathrm{E}-02$ & $8.8 \mathrm{E}-03$ \\
\hline $\mathrm{Pu} 240$ & 0 & $1.7 \mathrm{E}-02$ & $1.8 \mathrm{E}-02$ & $1.7 \mathrm{E}-02$ & $1.2 \mathrm{E}-02$ & 7.3E-03 & $2.9 \mathrm{E}-03$ & $5.4 \mathrm{E}-04$ & $6.7 \mathrm{E}-06$ \\
\hline Тc99 & 0 & 7.4E-12 & $5.2 \mathrm{E}-07$ & $5.4 \mathrm{E}-06$ & $5.7 \mathrm{E}-05$ & $8.8 \mathrm{E}-05$ & $1.8 \mathrm{E}-04$ & $2.8 \mathrm{E}-04$ & $4.8 \mathrm{E}-04$ \\
\hline Th229 & 0 & $9.0 \mathrm{E}-07$ & $1.9 \mathrm{E}-06$ & $3.7 \mathrm{E}-06$ & $8.6 \mathrm{E}-06$ & $1.6 \mathrm{E}-05$ & $2.7 \mathrm{E}-05$ & $9.5 \mathrm{E}-05$ & $1.6 \mathrm{E}-04$ \\
\hline U233 & 0 & $1.3 \mathrm{E}-06$ & $1.4 \mathrm{E}-06$ & $1.5 \mathrm{E}-06$ & $1.7 \mathrm{E}-06$ & $2.0 \mathrm{E}-06$ & $2.8 \mathrm{E}-06$ & $1.9 \mathrm{E}-05$ & $5.5 \mathrm{E}-05$ \\
\hline $\mathrm{U} 234$ & 0 & $2.4 \mathrm{E}-05$ & $2.7 \mathrm{E}-05$ & $2.7 \mathrm{E}-05$ & 2.7E-05 & $2.7 \mathrm{E}-05$ & $3.0 \mathrm{E}-05$ & $8.0 \mathrm{E}-05$ & $1.6 \mathrm{E}-04$ \\
\hline U236 & 0 & 0 & $4.2 \mathrm{E}-13$ & $9.1 \mathrm{E}-11$ & $1.1 \mathrm{E}-08$ & $8.2 \mathrm{E}-08$ & $7.2 \mathrm{E}-07$ & $1.1 \mathrm{E}-05$ & $3.2 \mathrm{E}-05$ \\
\hline U238 & 0 & $1.5 \mathrm{E}-18$ & $3.1 \mathrm{E}-13$ & $2.0 \mathrm{E}-10$ & $9.6 \mathrm{E}-09$ & $5.5 \mathrm{E}-08$ & 4.8E-07 & $8.1 \mathrm{E}-06$ & $2.3 \mathrm{E}-05$ \\
\hline $\mathrm{Pu} 242$ & 0 & $7.5 \mathrm{E}-05$ & $8.4 \mathrm{E}-05$ & $8.5 \mathrm{E}-05$ & $8.4 \mathrm{E}-05$ & $8.4 \mathrm{E}-05$ & 8.8E-05 & $3.4 \mathrm{E}-04$ & $2.7 \mathrm{E}-04$ \\
\hline $\operatorname{Th} 230$ & 0 & $2.5 \mathrm{E}-07$ & $5.7 \mathrm{E}-07$ & $1.2 \mathrm{E}-06$ & $2.9 \mathrm{E}-06$ & $5.7 \mathrm{E}-06$ & $1.1 \mathrm{E}-05$ & $4.1 \mathrm{E}-05$ & $5.0 \mathrm{E}-05$ \\
\hline Am241 & 0 & $6.5 \mathrm{E}-02$ & $3.3 \mathrm{E}-02$ & $6.7 \mathrm{E}-03$ & $5.4 \mathrm{E}-05$ & $1.8 \mathrm{E}-08$ & $6.7 \mathrm{E}-15$ & $5.7 \mathrm{E}-13$ & $1.6 \mathrm{E}-16$ \\
\hline $\mathrm{Pu} 238$ & 0 & $1.8 \mathrm{E}-03$ & $3.8 \mathrm{E}-05$ & $1.4 \mathrm{E}-08$ & $1.0 \mathrm{E}-18$ & $2.3 \mathrm{E}-19$ & $1.2 \mathrm{E}-19$ & $3.1 \mathrm{E}-25$ & 7.2E-24 \\
\hline Ac227 & 0 & $1.6 \mathrm{E}-06$ & $1.9 \mathrm{E}-06$ & $2.1 \mathrm{E}-06$ & $3.3 \mathrm{E}-06$ & $5.0 \mathrm{E}-06$ & $1.9 \mathrm{E}-05$ & $3.2 \mathrm{E}-04$ & $3.2 \mathrm{E}-04$ \\
\hline Cs 137 & 0 & $2.0 \mathrm{E}-07$ & $2.4 \mathrm{E}-12$ & $2.9 \mathrm{E}-22$ & $7.7 \mathrm{E}-29$ & 7.7E-29 & 7.7E-29 & $7.7 \mathrm{E}-29$ & 7.7E-29 \\
\hline $\mathrm{Pb} 210$ & 0 & 3.3E-09 & $1.5 \mathrm{E}-08$ & $5.7 \mathrm{E}-08$ & $2.6 \mathrm{E}-07$ & $7.2 \mathrm{E}-07$ & $2.0 \mathrm{E}-06$ & $8.6 \mathrm{E}-05$ & $7.5 \mathrm{E}-05$ \\
\hline $\mathrm{Ra} 226$ & 0 & $1.1 \mathrm{E}-09$ & 4.9E-09 & $1.8 \mathrm{E}-08$ & 8.3E-08 & $2.4 \mathrm{E}-07$ & $9.0 \mathrm{E}-07$ & $6.6 \mathrm{E}-05$ & $6.4 \mathrm{E}-05$ \\
\hline Sr90 & 0 & 2.9E-07 & $2.2 \mathrm{E}-12$ & $1.0 \mathrm{E}-22$ & $7.5 \mathrm{E}-29$ & $7.5 \mathrm{E}-29$ & $7.5 \mathrm{E}-29$ & $7.5 \mathrm{E}-29$ & $7.5 \mathrm{E}-29$ \\
\hline $\mathrm{U} 232$ & 0 & 7.0E-08 & $5.1 \mathrm{E}-10$ & $2.2 \mathrm{E}-14$ & $1.8 \mathrm{E}-27$ & $1.1 \mathrm{E}-28$ & $1.1 \mathrm{E}-28$ & $1.1 \mathrm{E}-28$ & $1.1 \mathrm{E}-28$ \\
\hline
\end{tabular}


Request: "Cost of individual packages, and the contributions to packaging cost (e.g. materials, at YMP handling, etc.). I've heard numbers ranging from 1 to $3 \mathrm{M} \$ /$ package. Not sure what dominates that cost."

Information Provided: The Waste Package cost, in FY03\$, is estimated at \$530k. The cost contributors (material, fabrication, and transportation) are only available in backup unpublished files. The WP pallet is mated with the WP in the surface facility, and thus its cost may also be pertinent to AFCI studies. The pallet cost is $\$ 59 \mathrm{k}$, with similar cost contributor categories. The total costs are based on a study of revised lid configuration included in YMP Baseline Change Proposal BCP-YMP-2003-005, dated October 2002. The cost contributor fractions in the backup unpublished files are based on the YMP FY2000 Total System Life Cycle Cost (TSLCC).

\section{3) Ventilation Cost}

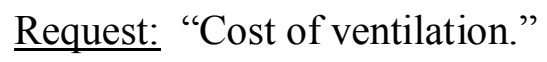

Information Provided: Ventilation costs in the YMP TSLCC are included in broader cost categories. Ventilation costs are only available in backup unpublished files. Costs have been estimated for exhaust shaft ventilation fans (including contributions for material, labor, and indirect cost elements). Operations costs have also been estimated with contributors from labor, supplies, design, procurement, and indirect cost elements. Ventilation costs in the backup unpublished files are based on the YMP FY2000 TSLCC.

\section{4) WP Temperature Limit and Basis}

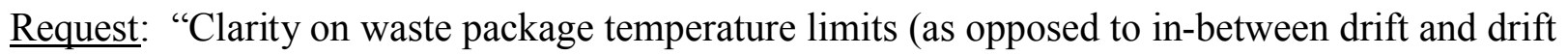
wall limits)."

Information Provided: Thermal limits are summarized by

YMP Report TDR-MGR-MD-000037, Rev 00, "Postclosure Modeling and Analyses

Design Parameters”, YMP Accession Number DOC.20041109.0002, October 2004.

The limits on repository temperature are set by several objectives.

- First, the pillars between drifts (5.5 m drifts spaced on $81 \mathrm{~m}$ centers) are to remain partially saturated, to permit ambient percolation and mobilized water to drain through the pillars toward the water table.

- Second, there is a drift wall temperature limit of $200^{\circ} \mathrm{C}$. This limit avoids high temperature mineral transformations that could increase mechanical stress in the underground environment.

- Third, there is a cladding temperature limit of $350^{\circ} \mathrm{C}$ to provide margin to clad failure by creep rupture.

DOE may choose to operate with a preclosure drift wall temperature limit of $96^{\circ} \mathrm{C}$, to preserve the option to modify the design to a fully subboiling temperature regime. 
It should be noted that these limits could be modified in requirements documents and analyses supporting the License Application.

5) Rate Limiting Steps for Waste Receipt at Yucca Mountain and for Emplacement in the $\underline{\text { Mountain }}$

Request: "Rate limiting steps on receiving waste at YMP and emplacing it into the mountain. Is it, for example, the \# of packages received?"

Information Provided: These steps depend on the surface facility throughput capacity and the underground emplacement equipment throughput capacity, which are in turn based on the mandated waste acceptance stream. Added constraints are a short construction schedule and limited funding in each construction year. A range of ramp-up strategies is possible. AFCI should be cautious about stating that a reprocessed waste stream could greatly change throughput, based on any comparison with the YM situation that is subject to the externallyconstrained waste stream, construction schedule, and capital cost limitations. 


\section{APPENDIX B \\ Draft Input: \\ OECD-NEA Study \\ "Impacts of Advanced Fuel Cycles on Waste Management Policy"}

\section{Results of thermal loading calculations for a repository in tuff}

Thermal design goals restrict repository utilization by limiting the loading density of the waste streams. In Yucca Mountain's nominal, high-temperature operating mode (HTOM), there are two thermal design limits that affect potential repository capacity:

a) The host rock must remain below $200{ }^{\circ} \mathrm{C}$ everywhere in the repository to limit mineral alteration. Meeting this limit at the drift wall results in limits on the linear thermal loading density along a drift, driven primarily by early-time fission product decay heat.

b) The temperature midway between storage drifts must remain below the boiling temperature of $96{ }^{\circ} \mathrm{C}$ at all times to permit drainage of water through the fracture network between drifts. This results in limits on areal thermal loading density primarily driven by long-term actinide decay heat. (Drifts in Yucca Mountain are assumed separated by $81 \mathrm{~m}$.)

The decay heat from each scenario's waste stream in units of W/TWhe was calculated out to 10,000 years using the ASIDE code for isotopic decay [1]. The maximum allowed loading density for each scenario was calculated using the AFCI Repository Thermal Model [2]. Results of these calculations are shown in Table I, where calculated utilization limits are expressed as linear and areal densities of waste from the indicated TWhe of produced energy. We note that relative to the 1a PWR baseline all recycle schemes raise utilization limits with the most prominent increase associated with the GCFR continuous recycle scheme $3 \mathrm{cv} 1$. For scenarios 1a, 1b, and 2a, the long-term areal limit driven by actinides determines the results. For the complete actinide recycle case in scenario $3 \mathrm{cv} 1$, the actinide decay heat drops dramatically. The results shown assume extended cooling or other thermal management of the short-term fission products to achieve the utilization limits shown. In addition, since these analyses realistically represent only the central region of a very large repository, the absolute Table I loading limits are likely to be conservatively low.

Table I Calculated Utilization Limits in an Unsaturated Tuff Repository

\begin{tabular}{|c|c|c|c|c|}
\hline Scenario/ Scheme & $1 \mathrm{a}$ & $1 \mathrm{~b}$ & $2 \mathrm{a}$ & $3 \mathrm{cv} 1$ \\
\hline Linear: TWhe $/ \mathrm{m}$ & 0.52 & 0.60 & 0.85 & 8.27 \\
\hline Areal: TWhe $/ \mathrm{m}^{2}$ & $6.42 \mathrm{E}-03$ & $7.35 \mathrm{E}-03$ & $1.05 \mathrm{E}-02$ & $1.02 \mathrm{E}-01$ \\
\hline Relative to PWR (1a) & 1.00 & 1.14 & 1.63 & 15.90 \\
\hline
\end{tabular}




\section{Results of performance calculations for a repository in tuff}

To evaluate the effect of the four fuel cycle scenarios on an unsaturated tuff repository, performance assessment calculations for radionuclide release and absorbed dose were carried out at ANL with the GOLDSIM [3] code using the "simplified site recommendation model" [4]. Given the simplified model, and the available repository, waste package and operation plan that have been developed for a specific fuel cycle (most similar to 1a), the relative performance is more meaningful than absolute performance. To permit scenario comparison, the results are presented in relative terms normalized to scenario 1a rather than in absolute values.

In the simplified model, waste streams make use of two types of waste packages with different performance characteristics. Spent fuel that is removed from the reactor and sent to the repository without processing is directly disposed in commercial spent nuclear fuel waste packages [5]. Alternatively, the waste stream from processed spent fuel is vitrified into waste forms made of high-level waste glass before placement in co-disposal waste packages [5].

The performance assessment calculations reported here utilized a scheme for areal loading common to all four scenarios. Scheme 1a was chosen as the reference case. The simplified model of direct disposal allows for disposal of 70,000 MT commercial spent nuclear fuel (the statutory limit) within 11770 commercial spent fuel waste packages spread over a repository footprint area of $4.02 \times 10^{6} \mathrm{~m}^{2}$, corresponding to an average areal loading of $17.4 \mathrm{~kg} / \mathrm{m}^{2}$. Directly substituting 70,000 MT of spent fuel from Scheme 1a into this model, the total electrical energy generated $\left(3.44 \times 10^{4}\right.$ TWhe) spread over this same footprint results in an areal TWhe loading density of $8.56 \times 10^{-3} \mathrm{TWhe} / \mathrm{m}^{2}$. (We note this value is $\sim 34 \%$ above the conservativelylow utilization limit calculated for Scheme 1a in Table I.)

For the waste streams of the remaining three fuel cycles, we assume the same total electrical generation as in the reference case $\left(3.44 \times 10^{4} \mathrm{TWhe}\right)$, the same repository footprint, and the same number of waste packages (11770). Each waste package is also assumed to contain the waste from generating the same amount of electrical energy; i.e, $3.44 \times 10^{4} / 11770=2.92$ TWhe. With Scheme 1b, the vitrified waste was assigned to 10231 co-disposal waste packages and the spent fuel to 1539 commercial spent fuel waste packages. For Schemes $2 \mathrm{a}$ and $3 \mathrm{cv} 1$, the vitrified waste was placed in 11770 co-disposal waste packages. This division of waste material among waste packages also results in the assumed initial isotopic waste package masses listed in Table II. In all Schemes the assumed average areal TWhe loading density is $8.56 \times 10^{-3} \mathrm{TWhe} / \mathrm{m}^{2}$. Note that this density is slightly above the conservative Table I utilization limit for Scheme $1 \mathrm{~b}$ and well below for Schemes $2 \mathrm{a}$ and $3 \mathrm{cv} 1$. Thus, the following results do not reflect any increased repository utilization (loading density) made possible in Schemes $2 \mathrm{a}$ and $3 \mathrm{cv} 1$, as the design analysis needed for repository re-optimization is beyond the scope of this study.

Figure 1 shows the total dose rate for the four cases. All the results are averages based on 1000 independent samples of the stochastic input parameters and are normalized by dividing by the peak dose rate for Scheme 1a. The curves in Fig. 1 indicate that Schemes 1b, 2a, and 3cv1 all lower the dose rate compared to the direct disposal case, Scheme 1a. However, the greatest reduction in the dose rate occurs for Scheme $3 \mathrm{cv} 1$, the fast reactor case. These results are not surprising since for Scheme 1a, the fraction of the dose rate contributed by actinides and their 
decay products is always greater than $90 \%$ after about 80,000 years. After 200,000 years the dose-rate contribution from actinides is essentially $100 \%$ for Schemes $1 \mathrm{a}, 1 \mathrm{~b}$, and $2 \mathrm{a}$, and even for Scheme 3cv1 is more than 70\%. During much of the time period prior to 60,000 years, the dose rate is dominated by ${ }^{99} \mathrm{Tc}$ and, to a lesser extent by ${ }^{129} \mathrm{I}$. The peak dose rate from fission products is higher for Schemes 1b, 2a, and 3cv1 than for Scheme 1a because all or most of the fission products are in the glass waste form. In the site recommendation total system performance assessment model, the glass waste form is not as durable as directly disposed commercial spent nuclear fuel (with credit taken for cladding). The fission product contribution to the dose rate is lower in Scheme $3 \mathrm{cv} 1$ than in Schemes $1 \mathrm{~b}$ and $2 \mathrm{a}$ because of the greater thermal efficiency specified for the gas-cooled fast reactor.

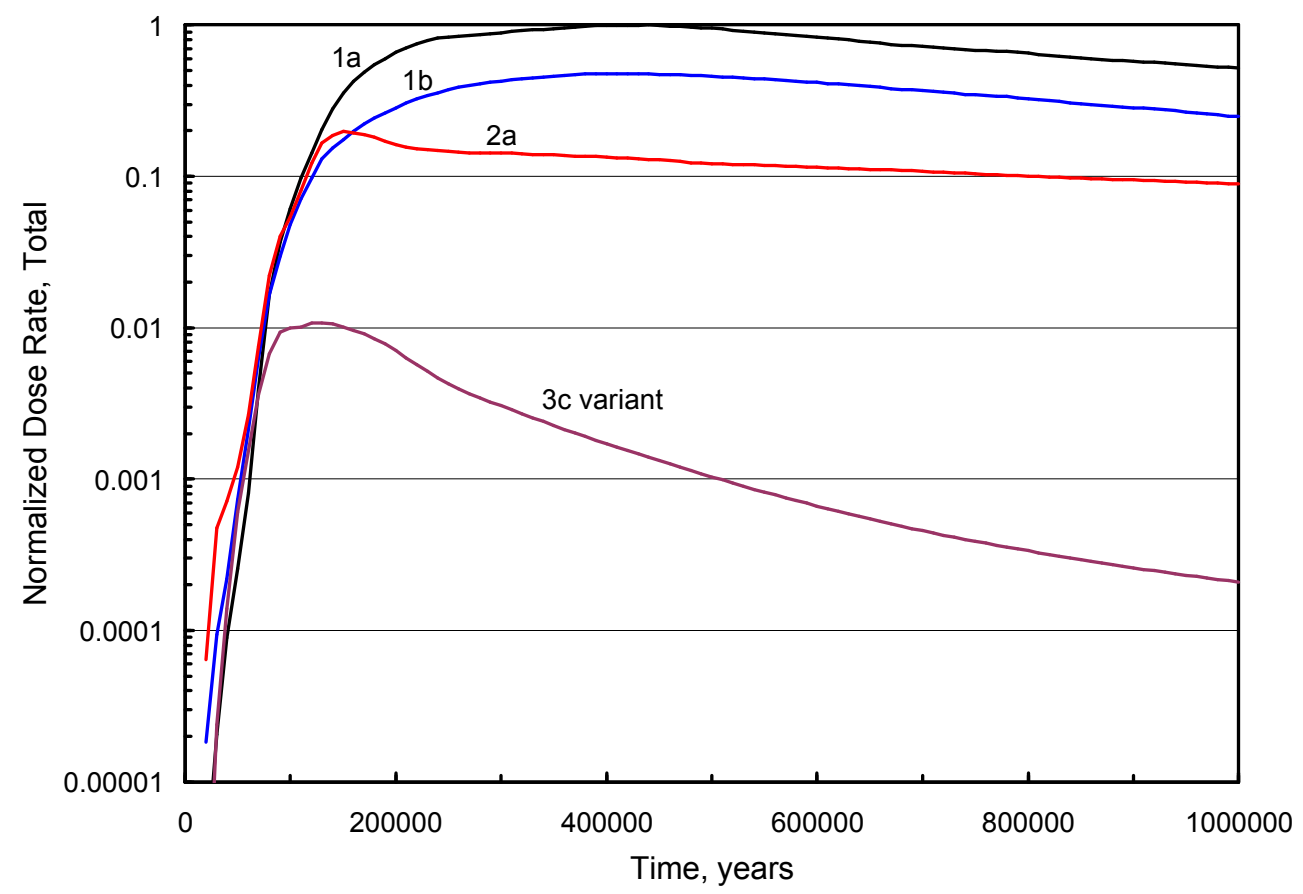

Fig 1: Normalized dose rates for Schemes 1a, 1b, 2a, and 3cv1 in an unsaturated tuff repository.

Appendix B References

1. Kalimullah and R. A. Wigeland, "The ASIDE Program for Analytical Solution of Isotopic Decay," October 1998, private communication.

2. R. A. Wigeland, T. H. Bauer, T. H. Fanning, and E. E. Morris, "Spent Nuclear Fuel Separations and Transmutation Criteria for Benefit to a Geologic Repository," WM'04 Conference, February 29-March 4, 2004, Tucson, AZ.

3. "User's Guide: GoldSim Graphical Simulation Environment" and "User's Guide: GoldSim Contaminant Transport Module," GoldSim Consulting Group, Golder Associates (May 2003 and April 2002).

4. Eric Zwahlen, Golder Assoc. Inc., Personal Communication, May 2002.

5. Yucca Mountain Science and Engineering Report, DOE/RW-0539 (May 2001). 